\title{
Comparative Study of Politeness in Ustaz Abdul Somad's Lecture with Ustazah Mama Dedeh's Lecture
}

\author{
Ermanto $^{1, *}$ David Syasli ${ }^{2}$ Novia Juita ${ }^{1}$
}

\author{
${ }^{1}$ Indonesian Language and Literature Department, Universitas Negeri Padang, Padang, Indonesia \\ ${ }^{2}$ SMPN 4 Batipuh. Batipuh, Indonesia \\ *Corresponding Author. Email: ermanto@fbs.unp.ac.id
}

\begin{abstract}
This study presents a comparisonthe principle of courtesy in the communication of Ustaz Abdul Somad's lecture with Ustazah Mama Dedeh. The object of this research is a comparison the principle of courtesy of Ustaz Abdul Somad with Ustazah Mama Dedeh in his lecture communication, until This research is categorized as qualitative descriptive research. The complete video taken from youtube is the source of the data for this research, the data obtained is associated withratio the principle of courtesy in the communication of Ustaz Abdul Somad and Ustazah Mama Dedeh lectures. Miles and Huberman's inductive technique is the basis for this research data analysis technique. Based on this model, analysis activities are carried out in four stages of activities, namely; (a) data collection, (b) data reduction, (c) data presentation, and (d) drawing conclusions and final results. This study found that the politeness principle of Ustaz Abdul Somad was dominated by the sympathy maxim of 24 utterances (32\%), while the politeness principle of Ustazah Mama Dedeh was dominated by the tact maxim of 35 utterances (41\%). Ustaz Abdul Somad utilizes the principle of courtesy maxim of sympathy as a polite and respectful speech act as well as speech that expresses sympathy for something to his congregation and has the power to do something for himself and his congregation. Ustazah Mama Dedeh used the principle of politeness, the maxim of tact to act politely and give his congregation the opportunity to do something fun, even though Ustazah Mama Dedeh's speech still showed that Ustazah Mama Dedeh had the power to deliver lectures.
\end{abstract}

Keywords: comparative, polite, ustaz, ustazah

\section{INTRODUCTION}

Comparative study is an interesting study to describe the similarities and differences in the appearance of a character with other characters. Each character has their own characteristics, but not all the characteristics of these characters are different, there are also the same characteristics. A comparative study is one option in analyzing the politeness of two well-known figures in Indonesia. Arikunto [1] states that comparative research will find similarities and differences about objects, people, work procedures, ideas, criticism of people, groups, of an idea, or work procedures. Surakhmad's opinion [2] comparative is descriptive research as an attempt to find a solution through analysis of causal relationships, namely selecting certain factors related to the situation or phenomenon under investigation and comparing one factor with other factors.

The figures who get a lot of attention in Indonesia are Islamic religious figures. Islamic religious figures are called Ustaz. Ustaz as a person who communicates and uses language in preaching orally can be studied comparatively. The word Ustaz means male religious leaders, for female religious leaders it is called ustazah. The meaning of the word cleric according to Purba [3] are religious teachers or male professors. According to Kuswandi [4] ustaz has the meaning, namely; first, as educators; second, people who are experts in one industry and teach others; third, a high-level academic nickname at a university, a term for a lecturer with a Doctorate, Professor or Professor title.

Ustaz is a religious figure who lectures is one example of a form of national communication. Polite national communication as a vital communication tool in this nation's national communication. The importance of polite communication to prevent radicalization and national disintegration. Islamic religious figures are influential figures for the Indonesian people, especially Muslims themselves. Polite communication of Islamic religious figures in national communication plays a very vital role in the perspective of deradicalization and the condition of a plural nation (pluralism). Islamic religious 
leaders should use the science of polite communication which can be seen from the aspect of polite speech acts. Culpeper [5] argues that the study of politeness has contributed to its popularity after being strengthened, although the conceptual core of this field still lies in pragmatics, politeness models have been applied and refined in various disciplines.

The phenomenon that is currently developing in national communication can be seen in the virtual communication of several Islamic religious figures, some are polite and some are not polite in communicating or giving lectures so that they have the potential to damage the sense of nationalism of the nation and influence or be followed by congregants who support or sympathize with these Islamic religious figures. . Supriyatno [6] believes that the Indonesian state can still be maintained if the current Indonesian government can develop two-way political communication between the center and the regions. Amen [6] explained that although communication often causes social conflict, the solution is also through communication. Herlina [7] put forward the conclusion that the phenomenon of mutual blasphemy on social media, especially Facebook has led to the phenomenon of intolerance. The problem of national communication is that communication that is not polite occurs to religious leaders and is also followed by the congregation or sympathizers of these figures.

The use of polite Indonesian when communicating is a reflection of the character and soul of the Indonesian nation. Islamic religious figures who use Indonesian in communicating or lecturing are a picture of high appreciation for the nation's culture (Law Number 24/2009 and Presidential Regulation Number 16/2010). Research on ethics and politeness in communicating with national political figures has been carried out, namely (1) Setiana, Anggun; Munaris \& Muhammad Fuad [8] argued that during the presidential candidate debate there were variations of official, business, familiar, literary, idiolect, and sociolect; (2) Romance [9] stated that President Jokowi's linguistic strategy in instilling ideology and manifesto government; (3) Sartini [10] concludes that language has tremendous power for political and imaging purposes; (4) Widyawari [11] states that polite speech can facilitate the cultivation of ideology; (5) Pusvita [12] argues that maxims and imperatives show that there is a balance of thought and action patterns with speech; (6) Ermanto [13] describes the language performance and communication politeness of West Sumatra executive officials.

Based on some of the studies above, it is concluded that the formulation of polite communication models for Islamic religious leaders has not been widely implemented. This research with the research above looks different because this research will formulate a polite communication model that is used by especially Islamic religious leaders who become role models for the congregation and the community. Polite communication is formulated by reviewing from the aspect of using Leech's politeness principles [14] which basically needs to be documented and socialized to all national and religious leaders, especially to the entire Indonesian nation.

The focus of this research is to review the comparison of the principles of courtesy in Ustaz Abdul Somad's lecture with Ustazah Mama Dedeh's lecture as a wellknown Islamic religious figure in Indonesia. Ustaz Abdul Somad was chosen because Ustaz Abdul Somad is one of the top lecturers with millions of followers. Sugandi research [15] stated that Ustaz Abdul Somad was a Ustaz with sharp and interesting studies that made many people like his lectures, even many of his lectures became viral on social media. Meanwhile, Ustazah Mama Dedeh was chosen because she conveyed her study in a frank or uncomplicated manner. Zaini [16] stated that Ustazah Mama Dedeh was famous for her speaking style in a straight line like the Betawi people, then her delivery was firm, fierce, but sometimes brought laughter from her congregation.

\section{METHOD}

The place of this research was carried out in Padang in stages. The time of this research takes place from February 9 to June 25, 2021. This research is a qualitative research with descriptive method. Descriptive understanding is research that is carried out only based on existing facts or phenomena that are empirically alive in the speaker. The purpose of this qualitative research is to produce descriptive data comparing the principles of courtesy in Ustaz Abdul Somad's lecture with Ustazah Mama Dedeh's lecture. The definition of qualitative methodology according to Bagdan and Taylor [17] is a research procedure that produces descriptive data in the form of spoken words from people and observed behavior. Arikunto [18] argues that descriptive research is not intended to test certain hypotheses, but only describes what it is about a variable, symptom or situation. This study aims to obtain a comparative description of the principles of courtesy in Ustaz Abdul Somad's lecture with Ustazah Mama Dedeh's lecture. 
The researcher is the instrument of this qualitative research itself and the researcher has been equipped with knowledge and theory related to the theme. The reduction, (c) data presentation, and (d) drawing conclusions and final results.

Table 1. Comparison of the Politeness Principles of Ustaz Abdul Somad with Ustazah Mama Dedeh

\begin{tabular}{|c|l|c|c|c|c|}
\hline No. & \multicolumn{1}{|c|}{ Politeness Principle } & \multicolumn{2}{c|}{ Ustaz Abdul Somad } & \multicolumn{2}{c|}{ Ustazah Mama Dedeh } \\
\hline 1 & Agreement Maxim & 20 & $27 \%$ & 14 & $16 \%$ \\
\hline 2 & Sympathy Maxim & 24 & $32 \%$ & 3 & $4 \%$ \\
\hline 3 & Modesty Maxim & 10 & $13 \%$ & 17 & $20 \%$ \\
\hline 4 & Approbation Maxim & 10 & $13 \%$ & 16 & $19 \%$ \\
\hline 5 & Tact Maxim & 11 & $15 \%$ & 35 & $41 \%$ \\
\hline & Total & 75 & $100 \%$ & 85 & $100 \%$ \\
\hline
\end{tabular}

instruments in this study were researchers using research tools in the form of a Lenovo laptop to process data and a Samsung A50 smartphone to help find and process information. In principle, this research data collection can be referred to as a data supply technique. Sudaryanto [19] stated that the meaning of 'data provision' is the provision of data that is truly data, the provision of data that is fully guaranteed to be valid. Meanwhile, what is stated by data collection techniques is actually only collecting data that is already available. The method used in this research is the method of listening. The listening method is the method used by researchers to obtain data by listening to the use of language, namely the communication of Ustaz Abdul Somad's lectures and Ustazah Mama Dedeh's lectures. The listening method is suitable for use in this study because it is used to obtain data by listening to the use of the principle of courtesy in Ustaz Abdul Somad's lecture with Ustazah Mama Dedeh's lecture.

The free-of-conversation (FoC) listening technique, recording, and note-taking is a data collection technique used in this study. FoC means that the writer downloads the video that has been recorded in the speech event without being involved in the speech event. So, in this case the researcher is only an observer, then after downloading the video the researcher must record or transcribe the data using tools such as Lenovo laptops, vaio notebooks and Samsung A50 smart phones. The data analysis technique of this research is based on Miles and Huberman's inductive technique [20]. Through this model, analysis activities are carried out through four stages of activities, namely, (a) data collection, (b) data

\section{RESULTS AND DISCUSSION}

\subsection{Research Result}

This study obtained the results of a comparison of the use of the principle of courtesy in Ustaz Abdul Somad's lecture with Ustazah Mama Dedeh's lecture. Comparison of the use of the principle of courtesy in Ustaz Abdul Somad's lecture with Ustazah Mama Dedeh's lecture can be seen in the following table of data analysis results;

\subsubsection{Ustaz Abdul Somad}

The politeness principle of Ustaz Abdul Somad is dominated by the sympathy maxim of 24 utterances (32\%). The principle of courtesy maxim of sympathy is a maxim in assertive illocutionary. According to Leech[14]The maxim of sympathy is to reduce the feeling of antipathy between oneself and others to the smallest possible extent, and to increase as much sympathy as possible between oneself and others. The following is an example of Ustaz Abdul Somad's speech that uses the principle of politeness maxim of sympathy:

(1) Kita semua tidak mau mendapatkan azab sama sekali maka doa kita "Ya Allah berikanlah kami keselamatan di dunia dan di akhirat" [21]

(1) We all don't want to get punished at all so our prayer is "O Allah, give us safety in this world and in the hereafter" [21]

The utterance (1) above shows that Ustaz Abdul Somad expressed the same feelings or desires as his congregation in order to avoid suffering because of the punishment given by Allah. Positive belief in God's 
power over mankind is the basis for Ustaz Abdul Somad in suggesting to do good or positive things that have a positive impact and avoid bad or negative actions that have negative effects on humans themselves. One of the ways presented by Ustaz Abdul Somad is to pray or ask Allah to give salvation in this world and in the hereafter. The prayer that is said is not for yourself, but for all those present and listeners of Ustaz Abdul Somad's lecture. Togetherness for goodness shows an attitude of sympathy to get good for themselves and for others or the congregation who attends the recitation with Ustaz Abdul Somad. This utterance is categorized as the principle of politeness maxim of sympathy because it shows that Ustaz Abdul Somad reduces the feeling of antipathy between himself and others or his congregation as small as possible and increases the sympathy as much as possible between himself and others or his congregation, as Leech argued [14]. The assertive illocutionary illocutionary utterance (1) can be seen from the prayer read by Ustaz Abdul Somad, namely grant us safety in this world and in the hereafter, which means honestly stating that Ustaz Abdul Somad is afraid of Allah's punishment, but still respects and protects the feelings of his congregation that they are both seek protection from Allah from all torments. Ustaz Abdul Somad's polite and respectful speech act in the principle of courtesy maxim of sympathy is a speech that expresses sympathy about something to his congregation and has the power to do something, namely praying for himself and others or for his congregation.

\subsubsection{Ustazah Mama Dedeh}

Ustazah Mama Dedeh's politeness principle is dominated by tact maxims as many as 35 utterances (41\%). The principle of politeness maxim of tact is a maxim in illocutionary and commissive illocutions. The maxim of tact according to Leech [14] that is, trying to make the loss of others as small as possible, and make the benefit of others as large as possible. The following is an example of the maxim of tact from Ustazah Mama Dedeh's speech:

(2) Kalau ditanya pengen, siapa yang pengen kaya? Ngacung, normal. Kalau Anda bilang nggak pengen itu abnormal. [22]

(2) If asked, who wants to be rich? Rise your hand!, normal. If you say you don't want it, that's abnormal. [22]
In speech (2) above, Ustazah Mama Dedeh asks a question about wanting to be rich or getting a lot of benefits to other people or his congregation. Then this question was responded to with a gesture of raising his hand which meant he wanted and commented positively or was justified by Ustazah Mama Dedeh. The rhetorical question given by Ustazah Mama Dedeh in the form of a sentence Ask who wants to be rich? Of course it will be answered by anyone because logically every human being needs sufficient material to meet his needs. The assumption that arises is that Ustazah Mama Dedeh's attitude is polite to provide benefits for other people or the congregation. Ustazah Mama Dedeh's comment that it was normal to support a polite attitude towards the choices made by his congregation, However, the abnormal statement on the exception for those who answered that they did not want to be rich showed that Ustazah Mama Dedeh had a role as a person who had the right to look down on other people who wanted other than what was offered or refused the benefits provided by Ustazah Mama Dedeh. This utterance (2) Ustazah Mama Dedeh causes a very small loss to other people or his congregation, and offers very large benefits to other people or his congregation to be categorized as the principle of courtesy maxim of tact according to Leech [14]. The impositive illocutionary uttered by Ustazah Mama Dedeh was an order to raise one's hand. The commissive illocution in speech (2) above is that the desire for wealth is something that is allowed or normal. Ustazah Mama Dedeh used polite speech acts and gave the congregation an opportunity to do something pleasant in the maxim of tact principle, however Ustazah Mama Dedeh's speech still showed that Ustazah Mama Dedeh had the power to deliver her lectures.

\section{CONCLUSION}

Based on the results of data analysis and discussion, this study obtained three conclusions. First, Ustaz Abdul Somad uses the principle of courtesy, the maxim of sympathy, which is a polite and respectful speech act and speech that expresses sympathy for something to his congregation and has the power to do something, namely praying for himself and others or for his congregation.

Second, Ustazah Mama Dedeh used the principle of courtesy, the maxim of tact to act politely and give his congregation the opportunity to do something fun, even though Ustazah Mama Dedeh's speech still showed that Ustazah Mama Dedeh had the power to deliver lectures. 
Third, the similarity of politeness principles in Ustaz Abdul Somad's speech with Ustazah Mama Dedeh is that they both try to display polite speech and show that they have power in lecturing. The difference between Ustaz Abdul Somad's speech and Ustazah Mama Dedeh's speech is that Ustaz Abdul Somad's speech act continues to show respect, respect and care for the feelings of his congregation, while Ustazah Mama Dedeh's speech act which shows his power in lecturing tends to look down on other people or his congregation who have different opinions with Ustazah. Mama Dedeh.

\section{REFERENCES}

[1] E. Lestari, "Studi Komparatif Tingkat Kesantunan Berbahasa dalam Proses Pembelajaran Bahasa Indonesia antara Siswa Kelas X Dengan Kelas Xi di M.A Aisyiyah Sungguminasa," Universitas Muhammadiyah Makasar, 2018

[2] W. Surakhmad, Pengantar Penelitian Ilmiah dasar metoda teknik, 8th ed. Bandung: Tarsito, 1998 .

[3] B. P. dan P. Bahasa, "Kamus Besar Bahasa Indonesia," Kementerian Pendidikan dan Kebudayaan Republik Indonesia, 2016. https://kbbi.kemdikbud.go.id/entri/ustaz (accessed Jul. 18, 2020).

[4] I. Kuswandi, "Logika Kebahagiaan Mahasantri Di Pesantren (Studi Kasus Di Kampus Idia Prenduan Sumenep Madura)," al-Balagh J. Dakwah dan Komun., vol. 2, no. 2, 2017, doi: 10.22515/balagh.v2i2.992.

[5] J. Culpeper, "Politeness and Impoliteness," Pragmatics, vol. 5, pp. 36-46, 2020, doi: 10.4324/9781003010043-5.

[6] Y. Supriyatno, "Peran Komunikasi Politik Pemerintah Dalam Mencegah Disintegrasi Bangsa," J. Kybernan, vol. 2, no. 2, pp. 1-11, 2011.

[7] L. Herlina, "Disintegrasi Sosial Dalam Konten Media Sosial Facebook," TEMALI J. Pembang. Sos., vol. 1, no. 2, pp. 232-258, 2018, doi: 10.15575/jt.v1i2.3046.

[8] A. Setiana, Munaris, and M. Fuad, "Aspek
Kebahasaan Jokowi pada Debat Calon Presiden dan Kegunaannya dalam Pembelajaran," J. Kata (Bahasa, Sastra, dan Pembelajarannya), vol. April, no. April, pp. 1-12, 2015.

[9] R. Asmara, "Strategi Kebahasaan Presiden Jokowi Dalam Menanamkan Ideologi Dan Manifesto Pemerintahan," Litera, vol. 15, no. 2 , pp. 379-388, 2016, doi: 10.21831/ltr.v15i2.11836.

[10] N. W. Sartini, "Bahasa dan Pencitraan: Strategi Kebahasaan dalam Wacana Politik," JJURNAL TUTUR, vol. 2, pp. 171-179, 2015, doi: 10.1017/CBO9781107415324.004.

[11] C. P. G. M. dan I. Z. Widyawari, "Representasi Ideologi Dalam Tuturan Santun Para Pejabat Negara Pada Talk Show Mata Najwa," Seloka J. Pendidik. Bhs. dan Sastra Indones., vol. 5, no. 1, pp. 1-11, 2016.

[12] W. D. Pusvita, "Kesantunan Maksim dan Imperatif Dalam Mata Najwa Episode 'Habibi Hari Ini' (Sebuah Kajian Pragmatik)," Int. Semin. Prasasti III Curr. Res. Linguist., pp. 857-862.

[13] E. Ermanto, Agustina, Emidar, Performa Bahasa dan Kesantunan Komunikasi Lisan Pejabat Sumatera Barat. Padang: Laporan penelitian Tahun I dengan Dana DIPA Universitas Negeri Padang Tahun Anggaran 2018, 2017.

[14] G. Leech, Prinsip-prinsip Pragmatik, 1st ed. Jakarta: UI-Press, 1993.

[15] M. A. S. Sugandhi, Irham, Manalullaili, "Persepsi Mahasiswa terhadap Metode Dakwah Ustadz Abdul Somad, Lc., MA (Studi kasus pada Mahasiswa Jurusan KPI Fakultas Dakwah dan Komunikasi UIN Raden Fatah Palembang angkatan 2015)," J. Komun. Islam, vol. 2, no. 2, pp. 15-16, 2018.

[16] A. Zaini, "Analisis Metode Ceramah Mamah Beraksi Di Indosiar Dengan Tema " Orang Ketiga Perusak Keluarga ,", AT-TABSYIR J. Komun. Penyiaran Islam, vol. 4, no. 2, pp. 213 228, 2016.

[17] L. J. Moleong, Metodologi Penelitian Kualitatif. Bandung: Remaja Rosdakarya., 2002. 
[18] S. Arikunto, Proses Penelitian Sesuatu Pendekatan Praktik. Jakarta: Rineka Cipta., 2006.

[19] Sudaryanto, Metode dan Aneka Teknik Analisis Bahasa (Pengantar Penelitian Wahana Kebudayaan Secara Linguistis). Yogyakarta: Duta Wacana University Press., 1993.

[20] M. Miles, M. B. \& Huberman, Analisis Data Kualitatif. Jakarta: Penerbit Universitas Indonesia, 1992.

[21] A. Somad, "https://www.youtube.com/results?search_quer $\mathrm{y}=$ ceramah + ustadz+abdul+somad," 2020 .

[22] E. Production, "https://www.youtube.com/results?search_quer $\mathrm{y}=$ ceramah + ustadzah + mama + dedeh," 2020 . 